\title{
Household air pollution and cancers other than lung: a meta-analysis
}

\author{
Sowmya Josyula ${ }^{1}$, Juan Lin ${ }^{1}$, Xiaonan Xue ${ }^{1}$, Nathaniel Rothman², Qing Lan², Thomas E Rohan ${ }^{1}$ \\ and H Dean Hosgood $1 I^{1}$
}

\begin{abstract}
Household air pollution (HAP) from solid fuel combustion contributes to $2.6 \%$ of the global burden of disease. HAP emissions are an established lung carcinogen; however, associations with other cancer sites have not been fully explored. We conducted a meta-analysis of 18 case-control studies. Using fixed-effects models, utilizing the adjusted odds ratios (OR) and $95 \%$ confidence intervals $(95 \% \mathrm{Cl})$ from each study, we evaluated the association between HAP and cervical neoplasia (663 cases and 1747 controls) and upper aero-digestive tract cancers (6022 cases and 15325 controls). We found that HAP was associated with cervical neoplasia ( $\mathrm{OR}=6.46 ; 95 \% \mathrm{Cl}=3.12-13.36 ; 4$ studies); oral $(\mathrm{OR}=2.44 ; 95 \% \mathrm{Cl}=1.87-3.19 ; 4$ studies; 1000 cases $/ 3450$ controls); nasopharyngeal $(\mathrm{OR}=1.80 ; 95 \% \mathrm{Cl}=1.42-2.29$; 6 studies; 2231 cases $/ 2160$ controls); pharyngeal $(\mathrm{OR}=3.56 ; 95 \% \mathrm{Cl}=2.22-5.70 ; 4$ studies; 1036 cases/3746 controls); and laryngeal ( $\mathrm{OR}=2.35 ; 95 \% \mathrm{Cl}=1.72-3.21 ; 5$ studies; 1416 cases/4514 controls) cancers. The elevated risk for esophageal cancer ( $\mathrm{OR}=1.92 ; 95 \% \mathrm{Cl}=0.82-4.49 ; 2$ studies; 339 cases/1455 controls) was non-significant. HAP was associated with cervical neoplasia among studies that accounted for HPV infection $(\mathrm{OR}=9.60 ; 95 \% \mathrm{Cl}=3.79-24.32)$ and smoking $(\mathrm{OR}=4.72 ; 95 \% \mathrm{Cl}=1.84-12.07)$. Similarly, our observed associations between HAP and upper aero-digestive tract cancers remained significantly elevated when analyses were restricted to studies that controlled for smoking. No significant publication bias was detected. Our results suggest that the carcinogenic effect of HAP observed for lung cancer may extend to other cancers, including those of the cervix and the upper aero-digestive tract. Further research is needed to confirm these associations in prospective studies.
\end{abstract}

Keywords: Solid fuels, Cervical cancer, Upper aero-digestive cancer, Meta-analysis, Risk factor

\section{Background}

Around three billion people depend on solid fuels for household energy both in developed and developing countries [1,2]. Solid fuel consists of mainly coal and various forms of biomass, such as wood, crop residues and animal dung. The type of solid fuel used varies by geographic location, with coal being primarily used in China and biomass being primarily used in India and Africa. The annual global health burden from household air pollution (HAP) is approximately 3.9 million deaths [3], accounting for $2.6 \%$ of global burden of disease. In the year 2000 it was estimated that 16,000 premature deaths have been attributed to lung cancer alone [1]. Based on animal and human studies, the World Health

\footnotetext{
* Correspondence: sowmya.josyula@einstein.yu.edu

${ }^{1}$ Department of Epidemiology \& Population Health, Albert Einstein College of Medicine, 1309, Belfer, Bronx New York, USA

Full list of author information is available at the end of the article
}

Organization's International Agency for Research on Cancer Working Group concluded that HAP from combustion of solid fuels, specifically coal, are carcinogenic to humans and particularly lung cancer [4-6]. Questions remain, however, as to if the carcinogenic potential of HAP extends beyond the lung.

Evidence suggests that polycyclic aromatic hydrocarbons (PAHs), a major HAP component, have carcinogenic properties on mucosal and endothelial lining of upper aero digestive tract from inhalation [7-9]. Studies have suggested that HAP may be associated with oral cancer and nasopharyngeal cancer [8-10]. Given that PAHs from smoking have been implicated in cervical cancer, the carcinogenic potential on the cervical and vaginal mucosal has been also explored for solid fuel use in human and animal models [11-13]. Given this background, we conducted a metaanalysis to assess the associations between HAP from all solid fuel types (coal, wood and mixed exposures) and
C Biomed Central

(c) 2015 Josyula et al.; licensee BioMed Central. This is an Open Access article distributed under the terms of the Creative Commons Attribution License (http://creativecommons.org/licenses/by/4.0), which permits unrestricted use, distribution, and reproduction in any medium, provided the original work is properly credited. The Creative Commons Public Domain Dedication waiver (http://creativecommons.org/publicdomain/zero/1.0/) applies to the data made available in this article unless otherwise stated. 
upper aero-digestive cancer and cervical neoplasia as they have yet to be summarized in the literature.

\section{Methods}

Studies that explored the association between upper aerodigestive and genital cancers with HAP, published between January 1970 and July 2014 were identified by searches of the PubMed and Science Citation Index databases using keywords related to indoor air pollution, cancer and cancer sites (Table 1 ). In addition, we manually searched the references from the articles that met our inclusion criteria.

The inclusion criteria for our study were: (i) epidemiological studies (case-control and cohort studies) that examined the association between HAP and these cancers; (ii) the study population's solid fuel use exposures were primarily derived from household cooking and/or heating and not from other forms of urban/outdoor air pollution or occupational exposures; and (iii) the results for the study population were not reported in another publication.

Studies were excluded if they were (i) studies written in languages other than English and Spanish; (ii) animal studies; (iii) studies examining only the carcinogens implicated in HAP (i.e., benzo (a) pyrene); or (iv) focused on occupational exposure to solid fuel usage or exposure to cooking oil fumes. The initial keyword searches yielded 285 manuscripts of which 60 were selected for abstract review. Of these studies that met our inclusion criteria, 18 studies were reviewed. All of these studies were case-control studies by design, except for one nested case-control study. Refer to Figure 1 for further details.

Data related to study design, geographical location, population setting, case selection criteria, control selection criteria, exposure assessment methods, the number of cases and controls, participation rates, gender distribution, the type of fuel used, and risk of cancer associated with exposure, crude odds ratio (OR) and 95\% confidence interval (95\% CI), adjusted odds ratio (OR) and $95 \% \mathrm{CI}$, the

Table 1 Search strings and key words

\begin{tabular}{|c|c|}
\hline $\begin{array}{l}\text { Search } \\
\text { Item }\end{array}$ & Keywords \\
\hline $\begin{array}{l}\text { Indoor air } \\
\text { pollution }\end{array}$ & $\begin{array}{l}\text { 'IAP' OR 'indoor air' OR 'indoor environment' OR 'pollution' } \\
\text { OR 'pollutant' OR 'exposure' OR 'fuel' OR 'fuels' OR 'coal' OR } \\
\text { 'coals' OR 'charcoal' OR 'charcoals' OR 'cake' OR 'cakes' OR } \\
\text { 'briquette' OR 'briquettes' OR 'solid fuel' OR 'solid fuels' OR } \\
\text { 'biomass' OR 'anthracite' OR 'bituminous' OR 'fossil fuel' OR } \\
\text { 'fossil fuels' OR 'lignite' OR 'subbituminous' OR 'stove' OR } \\
\text { 'stoves' OR 'chula' OR 'chulla' OR 'oven' OR 'ovens' OR } \\
\text { 'smoke' OR 'smoky' OR 'Wood' OR 'biomass' OR 'cooking oil' } \\
\text { 'heat*' OR 'cook*' OR 'light*' OR 'burn*' OR 'fumes*' }\end{array}$ \\
\hline $\begin{array}{l}\text { Cancer } \\
\text { site }\end{array}$ & $\begin{array}{l}\text { head and neck' OR 'oral' OR 'oropharyngeal' OR 'pharynx' } \\
\text { OR 'nasopharynx' OR 'hypopharynx' OR 'larngeal' OR } \\
\text { 'esophageal' OR 'cervical' OR 'genital' }\end{array}$ \\
\hline Cancer & $\begin{array}{l}\text { 'cancer' OR 'cancers' OR 'carcinoma' OR 'carcinomata' OR } \\
\text { 'neoplasm' OR 'neoplasms' OR 'tumor' OR 'tumors' OR } \\
\text { 'tumours' OR 'tumour' }\end{array}$ \\
\hline
\end{tabular}

variables adjusted for, and the limitations of the study were extracted from each study. Since there is no standardized method for HAP exposure assessment, we critically reviewed all the studies to determine the respective exposure assessment method. All studies utilized questionnairebased methods to determine exposures either qualitatively or quantitative. ORs were extracted for all fuel types (i.e., wood, coal) provided by each study. For studies that provided multiple ORs based on various exposure groups, the OR representing the highest exposure group was selected. For example, the groups that experienced the longest duration of exposure or the groups with substantial fuel burning in poorly ventilated kitchens were selected. Since HAP attributed to coal exposures tend to have higher carcinogenic potential than HAP attributed to wood for lung cancer [6], we selected ORs related to coal exposure for our primary analyses when multiple ORs were provided. We also extracted coal and wood specific ORs for our exploratory analysis.

Table 2 summarizes the studies that were included in the meta-analysis. For quality assurance each study was reviewed twice by the first author and three of the manuscripts were randomly selected and extracted by the senior author to examine the robustness of the data extracted. There was 100\% concordance between the two independent data extractions and between the extractions by the first and senior authors.

All statistical analyses were performed using the "meta" and "metafor" packages and in-house code developed in the $\mathrm{R}$ statistical language version 3.1.0. Heterogeneity among studies was determined using the $\mathrm{Q}$ test for heterogeneity. Summary ORs for cancers according to cancer site were then calculated using the adjusted OR and 95\% CIs from each independent study. If the adjusted odds ratio was unavailable we used crude odds ratio. Using random and fixed-effects models, summary ORs were calculated for the overall effect of each cancer site and exposure of interest. Given that the numbers of studies were too few to obtain a stable estimate of variance of random effects, and that cancer site-specific ORs calculated using randomeffects models were similar to those calculated using fixedeffects models, only results from fixed-effects models are presented. In addition, analyses were conducted to obtain summary ORs for studies that accounted for major known confounders, such as smoking status in upper aerodigestive cancers and HPV in cervical cancer. Exploratory analyses were also conducted based on specific type of fuel used. Publication bias was assessed by visual inspection of funnel plots (Additional file 1: Figure S1).

\section{Results}

Eighteen studies met our inclusion criteria [7,8,11-26]. Table 2 presents a brief summary of these studies with the following information: Setting (country and year of 


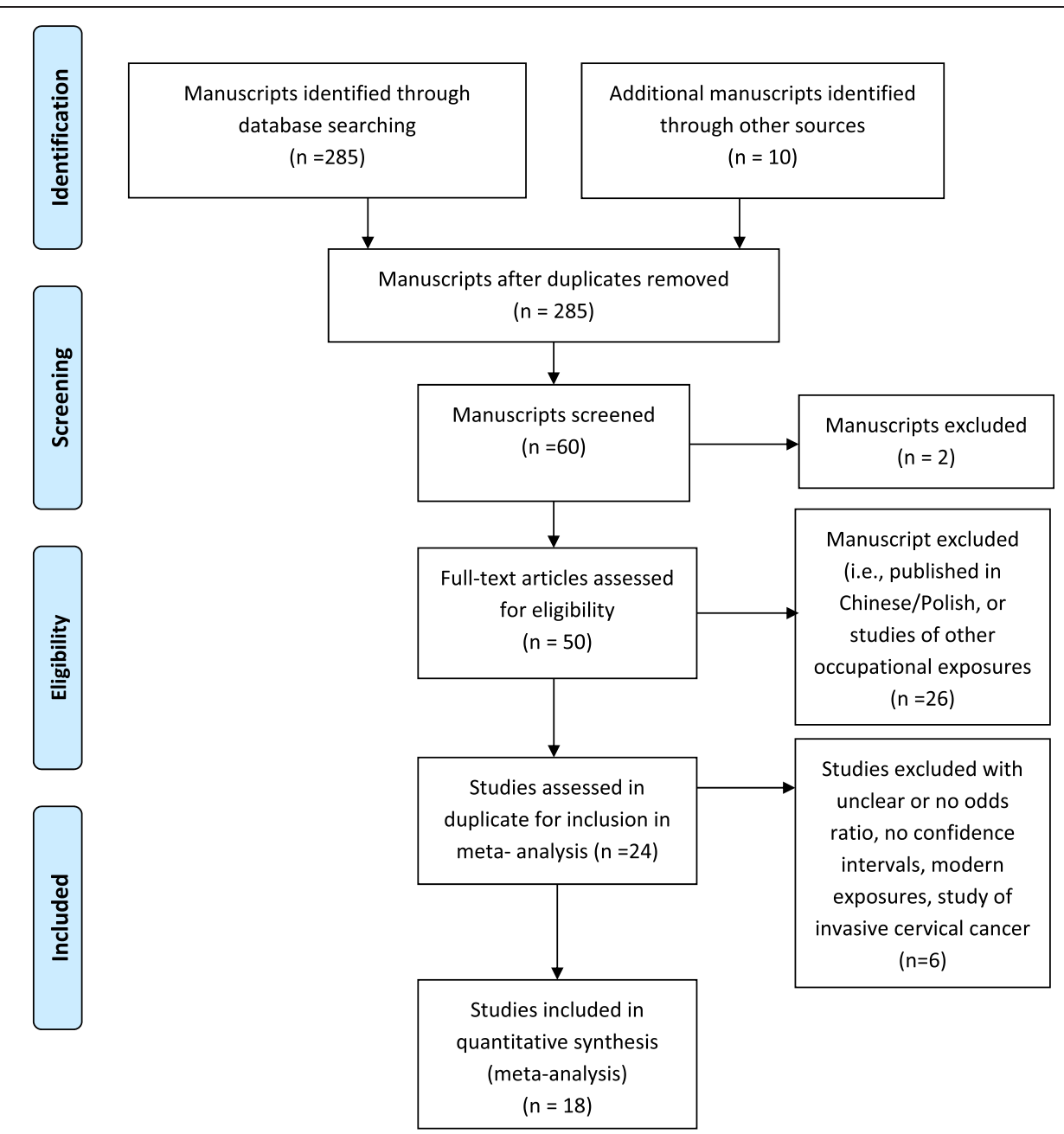

Figure 1 Literature review and selection criteria for a meta-analysis on household air pollution and the risk of cancers other than the lung.

study), type of cancer studied, case and control selection characteristics, criteria of inclusion and exclusion for cases and controls, participation rates for cases and controls, and percentage of males among cases and controls.

\section{Cervical neoplasia}

Four studies evaluated the association between precursor lesions of cervical cancer and HAP (Table 3) [11-13,18]. Of the four studies on precursor lesions of cervical cancer, two were conducted in South America and two in Asia. The total number of cases of carcinoma in-situ (CIN) was 663, which was compared to 1747 controls. The summary OR for the 4 studies was $6.46(95 \% \mathrm{CI}=3.12-13.36)$ (Figure $2 \mathrm{a})$. There was no heterogeneity $(\mathrm{p}=0.45)$ (Table 4$)$.

The two major risk factors for cervical neoplasia, HPV and smoking, have been independently controlled in some of the studies. The two studies that accounted for smoking remained significant $(\mathrm{OR}=4.72 ; 95 \% \mathrm{CI}=$ 1.84- 12.07) [11,12], as did the three studies that accounted for HPV status $(\mathrm{OR}=9.60 ; 95 \% \mathrm{CI}=3.79$ -
24.32) [12,13,18]. Only one study accounted for both HPV and smoking status concurrently, and it observed an elevated risk for high grade lesions associated with cooking for more than an hour each day, with poor ventilation $(\mathrm{OR}=8.10 ; 95 \% \mathrm{CI}=1.70$ - 39.00), among women aged 20 to 40 years, who never smoked and the OR was adjusted for HPV DNA load [12].

\section{Upper aero-digestive cancer sites}

Four studies (1000 cases/3450 controls) evaluated the association between oral cancer and HAP (Table 5), two were conducted in South America and two in Europe [7,23-25]. Summary OR was 2.44 (95\% CI = 1.87-3.19) (Figure 2b) and there was no significant heterogeneity $(p=0.93)$ (Table 4). The summary OR for the three studies that accounted for smoking status, a significant risk factor for oral cancer, was found to be 2.56 (95\% CI = 1.80-3.64) [7,24,25].

Six studies (2231 cases/2160 controls) estimated the risk of nasopharyngeal carcinoma from HAP. Four of these studies were conducted in Asia and two in Africa 
Table 2 Summary of the 18 case-control studies included in a meta-analysis of the risk of cancers other than lung associated with household air pollution

\begin{tabular}{|c|c|c|c|c|c|c|c|c|c|c|c|}
\hline Study & Setting & $\begin{array}{l}\text { Cancer site } \\
\text { studied }\end{array}$ & Cases & Controls & $\begin{array}{l}\text { Type of case- } \\
\text { control study }\end{array}$ & Definition of cases & Definition of controls & $\begin{array}{l}\text { P.r. } \\
\text { case }\end{array}$ & $\begin{array}{l}\text { P.r } \\
\text { control }\end{array}$ & $\begin{array}{l}\% \text { male } \\
\text { case }\end{array}$ & $\begin{array}{l}\% \text { male } \\
\text { control }\end{array}$ \\
\hline \multirow{3}{*}{$\begin{array}{l}\text { Pintos (1998) } \\
{[25]}\end{array}$} & \multirow{3}{*}{$\begin{array}{l}\text { Brazil: } \\
\text { 1987-89 }\end{array}$} & Oral & 373 & 1,568 & \multirow[t]{3}{*}{ Hospital based } & \multirow{3}{*}{$\begin{array}{l}\text { Incident cancers. Excluded: } \\
\text { salivary gland, nasopharynx } \\
\text { cancers }\end{array}$} & \multirow{3}{*}{$\begin{array}{l}\text { Matched: sex, age, admission time. } \\
\text { Excluded disease: cancers \& mental }\end{array}$} & \multirow[t]{3}{*}{100} & \multirow[t]{3}{*}{100} & \multirow[t]{3}{*}{100} & \multirow[t]{3}{*}{100} \\
\hline & & Pharyngeal & 217 & 1,568 & & & & & & & \\
\hline & & Laryngeal & 194 & 1,568 & & & & & & & \\
\hline \multirow{4}{*}{$\begin{array}{l}\text { Sapkota } \\
\text { (2012) [7] }\end{array}$} & \multirow{4}{*}{$\begin{array}{l}\text { Europe: } \\
2003\end{array}$} & Oral & 295 & 1,018 & \multirow{4}{*}{$\begin{array}{l}\text { Hospital \& } \\
\text { population } \\
\text { based }\end{array}$} & \multirow[t]{4}{*}{ Age: $20-79$, histologically confirmed } & \multirow{4}{*}{$\begin{array}{l}\text { Matched: age, sex, residence, } \\
\text { no cancer or tobacco disease }\end{array}$} & \multirow[t]{4}{*}{100} & \multirow[t]{4}{*}{90 to 96} & \multirow[t]{4}{*}{78} & \multirow[t]{4}{*}{85} \\
\hline & & Pharyngeal & 201 & 1,040 & & & & & & & \\
\hline & & Laryngeal & 383 & 916 & & & & & & & \\
\hline & & Esophageal & 186 & 1,110 & & & & & & & \\
\hline \multirow{2}{*}{$\begin{array}{l}\text { Sapkota } \\
\text { (2008) [14] }\end{array}$} & \multirow{2}{*}{$\begin{array}{l}\text { India: } \\
\text { 2001-04 }\end{array}$} & Hypopharyngeal & 513 & 718 & \multirow{2}{*}{$\begin{array}{l}\text { Hospital \& } \\
\text { population } \\
\text { based }\end{array}$} & \multirow[t]{2}{*}{ Age $<80$, residence $>1$ year } & \multirow{2}{*}{$\begin{array}{l}\text { Matched: age, sex, residence, } \\
\text { no tobacco or alcohol diseases }\end{array}$} & \multirow[t]{2}{*}{100} & \multirow[t]{2}{*}{ \#\# } & \multirow[t]{2}{*}{$87.5 \wedge$} & \multirow[t]{2}{*}{85} \\
\hline & & Laryngeal & 511 & 718 & & & & & & & \\
\hline \multirow{3}{*}{$\begin{array}{l}\text { Dietz (1995) } \\
\text { [24] }\end{array}$} & \multirow{3}{*}{$\begin{array}{l}\text { Germany: } \\
\text { 1989-92 }\end{array}$} & Oral & 100 & 400 & \multirow[t]{3}{*}{ Hospital based } & \multirow[t]{3}{*}{ Diagnosed cancer } & \multirow[t]{3}{*}{ Matched: sex, residence, age } & \#\# & \#\# & $\# \#$ & \#\# \\
\hline & & Pharyngeal & 105 & 420 & & & & & & & \\
\hline & & Laryngeal & 164 & 656 & & & & & & & \\
\hline $\begin{array}{l}\text { Franco (1989) } \\
{[23]}\end{array}$ & $\begin{array}{l}\text { Brazil: } \\
\text { 1986-88 }\end{array}$ & Oral & 232 & 464 & $\begin{array}{l}\text { Hospital \& } \\
\text { population } \\
\text { based }\end{array}$ & $\begin{array}{l}\text { Malignancies of lip and salivary } \\
\text { glands excluded. }\end{array}$ & $\begin{array}{l}\text { Matched: sex, age, admission } \\
\text { time. cancers, mental disorder } \\
\text { excluded }\end{array}$ & 100 & 100 & 87 & 87 \\
\hline $\begin{array}{l}\text { Maier (1997) } \\
{[22]}\end{array}$ & $\begin{array}{l}\text { Germany: } \\
\text { 1988-89 }\end{array}$ & Laryngeal & 164 & 656 & Hospital based & Diagnosed with a time lapse $<3$ years & Matched for age, residence & \#\# & \#\# & 100 & 100 \\
\hline $\begin{array}{l}\text { Chang-Claude } \\
\text { (1990) [21] }\end{array}$ & $\begin{array}{l}\text { China: } \\
1988\end{array}$ & Esophageal & 153 & 345 & $\begin{array}{l}\text { Population } \\
\text { based }\end{array}$ & Diagnosed cancer & $\begin{array}{l}\text { No family history esophageal } \\
\text { cancer or dysplasia }\end{array}$ & 62 & 62 & 24 & 81 \\
\hline $\begin{array}{l}\text { Ferrera } \\
(2000)[20]\end{array}$ & $\begin{array}{l}\text { Honduras: } \\
\text { 1993-95 }\end{array}$ & Invasive cervical & 99 & 197 & Hospital based & $\begin{array}{l}\text { Age 20-65, no treatment, } \\
\text { residence }>6 \text { months. Poor } \\
\text { mental health excluded }\end{array}$ & $\begin{array}{l}\text { Matched: age, normal cervix, } \\
\text { no history of hysterectomy } \\
\text { or conization, }\end{array}$ & 100 & 100 & 0 & 0 \\
\hline $\begin{array}{l}\text { Velema } \\
\text { (2002) [18] }\end{array}$ & $\begin{array}{l}\text { Honduras: } \\
\text { 1993-95 }\end{array}$ & $\mathrm{CIN}$ & 125 & 241 & Hospital based & Diagnosis & $\begin{array}{l}\text { Matched: age, normal cervix, } \\
\text { Pap smear; never received } \\
\text { treatment }\end{array}$ & 100 & 100 & 0 & 0 \\
\hline $\begin{array}{l}\text { Wu (2004) } \\
{[11]^{* * *}}\end{array}$ & $\begin{array}{l}\text { Taiwan: } \\
\text { 1999-2000 }\end{array}$ & $\mathrm{CIN}>2$ & 116 & 197 & $\begin{array}{l}\text { Population } \\
\text { based }\end{array}$ & Age 19 and above with $\mathrm{CIN}>2$ & $\begin{array}{l}\text { Matched: age, residence; } \\
\text { negative pap smear }\end{array}$ & 100 & 100 & 0 & 0 \\
\hline $\begin{array}{l}\text { Lee }(2010) \\
{[12]}\end{array}$ & $\begin{array}{l}\text { Taiwan: } \\
\text { 2003-08 }\end{array}$ & $\mathrm{CIN}$ & 324 & 1,200 & $\begin{array}{l}\text { Population } \\
\text { based }\end{array}$ & $\begin{array}{l}\text { All socioeconomic levels age } 20 \text { to } \\
75, \mathrm{CIN}>1\end{array}$ & $\begin{array}{l}\text { Matched: residence, time } \\
\text { of Pap smear, age; negative } \\
\text { Pap smear }\end{array}$ & 89 & 93 & 0 & 0 \\
\hline $\begin{array}{l}\text { Torres (2006) } \\
{[13]}\end{array}$ & $\begin{array}{l}\text { Colombia: } \\
\text { 2002-03 }\end{array}$ & $\mathrm{CIN}$ & 98 & 109 & Hospital based & $\begin{array}{l}\text { CIN 2, 3. Exclude: chemotherapy, } \\
\text { chronic disease, family cancer, ill }\end{array}$ & $\begin{array}{l}\text { Matched: age, residence; } \\
\text { normal histology; no HPV } \\
\text { treatment }\end{array}$ & \#\# & \#\# & 0 & 0 \\
\hline $\begin{array}{l}\text { Feng (2009) } \\
{[15]}\end{array}$ & $\begin{array}{l}\text { Africa: } \\
\text { 2001- } 04\end{array}$ & NPC & 636 & 615 & Hospital based & $\begin{array}{l}\text { Incident \& prevalent cases, > } 15 \text { years, } \\
\text { treated in public hospitals. }\end{array}$ & $\begin{array}{l}\text { Matched: center, age, sex, } \\
\text { urban/rural; non NPC }\end{array}$ & 90 & \#\# & 71 & 68 \\
\hline $\begin{array}{l}\text { Yu (1988) } \\
{[26]}\end{array}$ & $\begin{array}{l}\text { China: } \\
\text { 1984-86 }\end{array}$ & NPC & 128 & 174 & $\begin{array}{l}\text { Population } \\
\text { based }\end{array}$ & Mothers of diagnosed NPC, age $<45$ & Matched: residence, race sex age & 100 & 100 & 71 & 71 \\
\hline
\end{tabular}


Table 2 Summary of the 18 case-control studies included in a meta-analysis of the risk of cancers other than lung associated with household air pollution (Continued)

\begin{tabular}{|c|c|c|c|c|c|c|c|c|c|c|c|}
\hline Yu (1986) [8] & $\begin{array}{l}\text { Hong } \\
\text { Kong: } 1981\end{array}$ & NPC & 250 & 250 & $\begin{array}{l}\text { Population } \\
\text { based }\end{array}$ & Incident cases, Chinese, age $<35$ & $\begin{array}{l}\text { Matched: sex, age, ethnicity, } \\
\text { marital status, education. }\end{array}$ & 100 & 100 & 64 & 64 \\
\hline $\begin{array}{l}\text { Jeannel } \\
\text { (1990) [16] }\end{array}$ & $\begin{array}{l}\text { Tunisia: } \\
\text { 1986- } 87\end{array}$ & NPC & 80 & 160 & $\begin{array}{l}\text { Population } \\
\text { based }\end{array}$ & Diagnosed cases & Matched: sex, age, residence. & 100 & 100 & 67 & 67 \\
\hline $\begin{array}{l}\text { Zheng (1994) } \\
\text { [17] }\end{array}$ & $\begin{array}{l}\text { China: } \\
1986\end{array}$ & NPC & 88 & 176 & $\begin{array}{l}\text { Population } \\
\text { based }\end{array}$ & Incident NPC & Matched: sex, age, residence. & 100 & 100 & 73 & 73 \\
\hline $\begin{array}{l}\text { Guo (2009) } \\
{[19]}\end{array}$ & $\begin{array}{l}\text { China: } \\
\text { 2004-05 }\end{array}$ & NPC & 1,049 & 785 & Hospital based & Incident and prevalent cases & $\begin{array}{l}\text { Matched: age, sex, residence; } \\
\text { EBV antibodies +, no NPC; } \\
\text { Excluded: minority, family } \\
\text { members enrolled }\end{array}$ & \#\# & $\# \#$ & 72 & 72 \\
\hline
\end{tabular}

\#\# Not provided; CIN = Cervical Intraepithelial Neoplasm; NPC: Nasopharyngeal Carcinoma; p.r = participation rates; \% males: gender distribution in the study; ${ }^{* * *}$ only nested case control study; setting = geographic area of study and year of participant enrollment; $\wedge$ average $\%$ for all cancers. 
Table 3 Summary of studies analyzing cervical neoplasia risk associated with household air pollution

\begin{tabular}{|c|c|c|c|c|c|c|c|}
\hline Study & $\begin{array}{l}\text { Cases } \\
\text { (N) }\end{array}$ & $\begin{array}{l}\text { Controls } \\
\text { (N) }\end{array}$ & $\begin{array}{l}\text { Grade } \\
\text { CIN }\end{array}$ & Exposure definition & Odds ratio & $\begin{array}{l}\text { Account for } \\
\text { HPV }\end{array}$ & Variables adjusted for \\
\hline Velema (2002) [18] & 125 & 241 & I, II, III & $\begin{array}{l}\text { HPV }+ \text {, CIN, wood } \\
\text { smoke exposure } \\
35+\text { years }\end{array}$ & $5.69(1.00-2.70)$ & Yes & $\begin{array}{l}\text { HPV, education, parity, } \\
\text { no: sex partners, } \\
\text { age sexual debut }\end{array}$ \\
\hline Wu (2004) [11] & 116 & 197 & $>\|$ & $\begin{array}{l}\text { Age }>40, \text { never used } \\
\text { fume extractor }\end{array}$ & $3.46(1.08-11.10)$ & No & $\begin{array}{l}\text { Age, education, smoking, } \\
\text { no: prior pap smears, age } \\
\text { at sexual debut, chefs }\end{array}$ \\
\hline Lee (2010) [12] & 324 & 1,200 & | ||, ||| & $\begin{array}{l}\text { Cooked at age } 20 \text { to } 40 \text {, } \\
\text { HGSIL+, > } 1 \text { hour cooking, } \\
\text { poor ventilation }\end{array}$ & $8.40(1.7-41.10)$ & Yes & $\begin{array}{l}\text { Age, marital status, education, } \\
\text { age at sexual debut, smoking, } \\
\text { HPV DNA load and chef }\end{array}$ \\
\hline Torres (2006) [13] & 98 & 109 & I, II, III & Exposure for $>45$ years & $16.10(3.55-73.50)$ & Yes & $\begin{array}{l}\text { HPV status, age at first sexual } \\
\text { intercourse, yrs. education, } \\
\text { rural vs urban }\end{array}$ \\
\hline
\end{tabular}

$[8,15-17,19,26]$. Summary OR was 1.80 (95\% CI $=1.42$ 2.29) (Figure 2f) and the test for heterogeneity was not significant $(\mathrm{p}=0.06)$ (Table 4). Many of these studies explored the risk factors for nasopharyngeal cancer including dietary risk factors and ventilation in the kitchen. Only two of the studies provided an adjusted OR for the risk of HAP and nasopharyngeal cancer and the summary OR for these two studies remained statistically significant $(\mathrm{OR}=2.25$; $95 \% \mathrm{CI}=1.59-3.18)[15,19]$. The only study that accounted for EBV infection and smoking status observed an increased

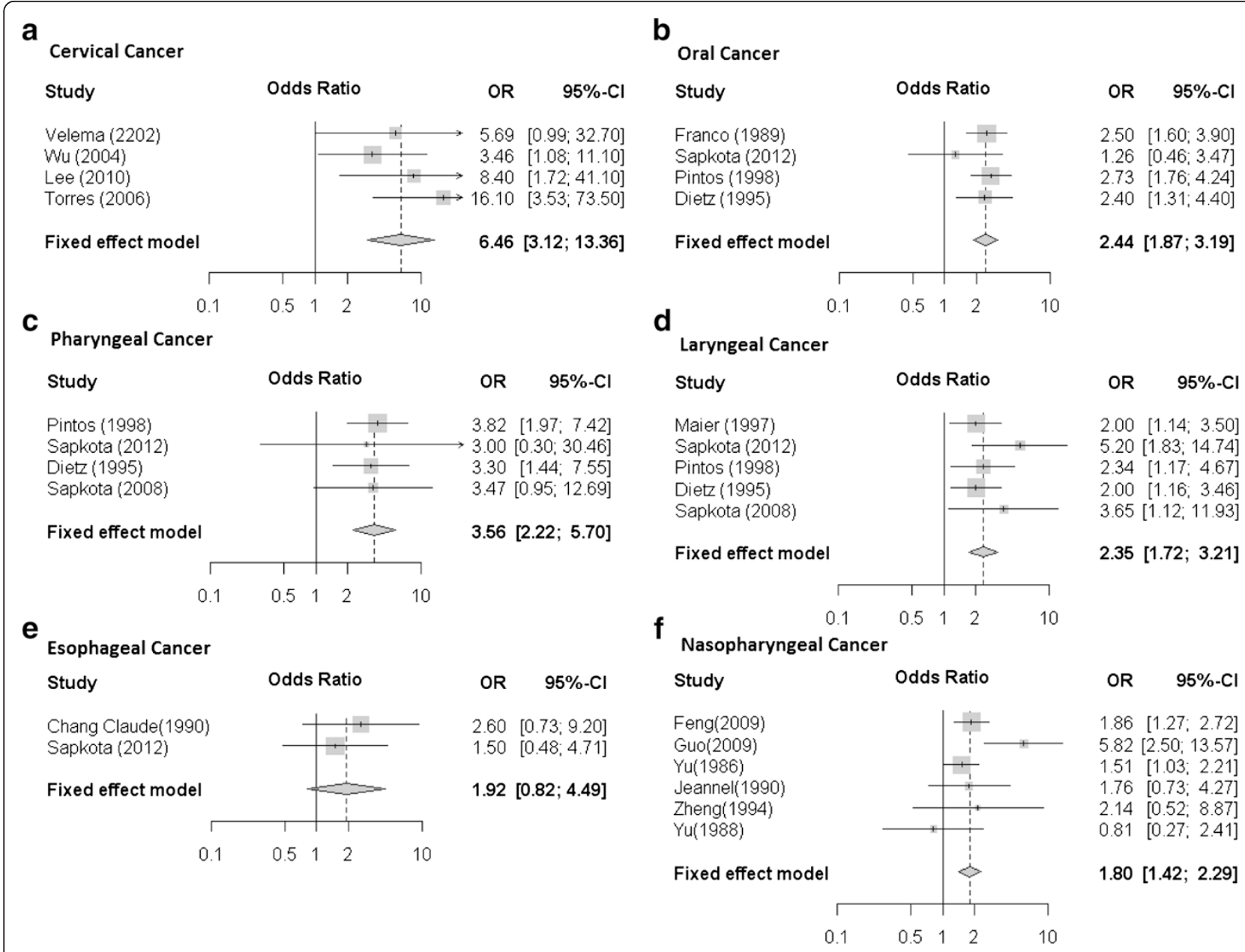

Figure 2 Forest plots for the relative strength of the summary OR for for (a) Cervical cancer, (b) Oral cancer, (c) Pharngeal cancer (d) Laryngeal cancer (e) Esophageal cancer (f) nasopharyngeal cancer. 
Table 4 Meta-analysis results of literature evaluating the risk of cancers other than the lung associated with household air pollution

\begin{tabular}{|c|c|c|c|c|c|c|}
\hline \multirow[b]{2}{*}{ Cancer site } & \multicolumn{3}{|c|}{ Number of } & \multicolumn{2}{|c|}{ Fixed effects model } & \multirow{2}{*}{$\begin{array}{l}\text { Heterogeneity } \\
\text { (p) }\end{array}$} \\
\hline & Studies & Cases & Controls & $\mathrm{OR}^{*}$ & $95 \% \mathrm{Cl}$ & \\
\hline Cervical & 4 & 663 & 1747 & 6.46 & $3.12-13.36$ & 0.45 \\
\hline Oral & 4 & 1000 & 3450 & 2.44 & $1.87-3.19$ & 0.93 \\
\hline Nasopharyngeal & 6 & 2231 & 2160 & 1.80 & $1.42-2.29$ & 0.06 \\
\hline Pharyngeal & 4 & 1036 & 3746 & 3.56 & $2.22-5.70$ & 0.99 \\
\hline Esophageal & 2 & 339 & 1455 & 1.92 & $0.82-4.49$ & 0.53 \\
\hline Laryngeal & 5 & 1416 & 4514 & 2.35 & $1.72-3.21$ & 0.49 \\
\hline
\end{tabular}

*Summary OR was calculated using fixed effects model for overall effect of each cancer site.

risk associated with HAP and nasopharyngeal cancer $(\mathrm{OR}=$ 5.82; 95\% CI = 2.50 - 13.57) [19].

Four studies (1036 cases/3746 controls) assessed the risk of pharyngeal cancer associated with HAP (Table 5). These studies were conducted in Asia, South America and Europe $[7,14,24,25]$. The risk of pharyngeal cancer associated with HAP in these four studies was $3.56(95 \% \mathrm{CI}=$ 2.22- 5.70) (Figure 2c) and there was no substantial heterogeneity $(p=0.99)$ (Table 4$)$. All 4 studies adjusted for smoking status.

Two studies (339 cases/1455 controls), which were conducted in Asia and Europe [7,21], evaluated esophageal cancer risk and HAP (Table 5). Summary OR for these was 1.92 (95\% CI = 0.82- 4.49) (Figure 2e), with no heterogeneity $(\mathrm{p}=0.53)$ (Table 4$)$. Only one study adjusted for smoking and the adjusted OR was 1.50 (95\% CI $=0.48$ 4.71) [7].

Five studies (1416 cases / 4514 controls) evaluated the risk of laryngeal cancer associated with HAP (Table 5). Three of these studies were conducted in European countries, one in Asia and one in South America [7,14,22,24,25]. All the five studies accounted for smoking and the summary OR was 2.35 (95\% CI = 1.72- 3.21) (Figure 2d), with no heterogeneity $(\mathrm{p}=0.49)($ Table 4$)$.

\section{Type of fuel use}

We conducted exploratory analyses to estimate fuel typespecific summary ORs (Table 6). These analyses are considered exploratory due to the limited number of studies included in the analyses.

In precancerous cervical lesions, the summary OR for wood-specific exposure was $10.29(95 \% \mathrm{CI}=3.27$ - 32.40) $[11,12]$. For the upper aero-digestive cancers, the summary OR based on exposure to wood smoke depending on cancer site were as follows: oral cancer $(\mathrm{OR}=2.45$; 95\% CI $=1.81$ 3.30 ), pharyngeal cancer $(\mathrm{OR}=2.56$; $95 \% \mathrm{CI}=1.20$ - 5.49), laryngeal cancer $(\mathrm{OR}=1.54 ; 95 \% \mathrm{CI}=0.81-2.94)$, esophageal cancer $(\mathrm{OR}=2.13 ; 95 \% \mathrm{CI}=1.05-4.30)$ and nasopharyngeal cancer (OR $=1.77 ; 95 \% \mathrm{CI}=1.07$ to 2.91 ) (Table 6). Coal use was associated with increased risk of cervical, pharyngeal, and laryngeal cancers; however, these estimates were based on a limited number of studies.

\section{Discussion}

Globally, 50\% of all households and 90\% of rural households continue to depend on solid fuels for cooking and heating [2]. An estimated 2.6\% of the global burden of disease has been attributed to HAP [3]. With the existing evidence for the biological plausibility of HAP exposure potentially contributing to cervical neoplasia [27,28] and upper aero-digestive cancers [28,29] it is important to estimate this relationship.

Our meta-analysis of epidemiological studies confirms the results observed in animal studies [28,29], suggesting that the risk of upper aero-digestive cancers is associated with HAP. Our meta-analysis observed that HAP is associated with increased risk for oral, nasopharyngeal, pharyngeal, and laryngeal cancers. However, the increased risk noted with esophageal cancers was not statistically significant. The increased risks we observed seem to be independent of other risk factors such as smoking and age.

The carcinogenic potential of HAP has been previously evaluated. HAP is known to cause an increase household air levels of sulfur dioxide, carbon monoxide, fluorine, and known carcinogens such as polycyclic aromatic hydrocarbons (PAHs), benzene, arsenic, 1,3butadiene and formaldehyde, [30,31]. These HAP constituents have been implicated in various malignant and nonmalignant diseases of organs on the route of exposure such as the respiratory tract, as well as the cardiovascular system [3]. Individual genetic variation and exposure to HAP is known to increase susceptibility to lung cancer [32].

The type of, and relative proportions of, carcinogens released varies by the type of fuel used [33]. Studies have found that combustion of coal increases the levels of PAHs, benzene, formaldehyde, silica and arsenic. The composition of these emissions vary from region to region [5]. Wood has been associated with elevated levels of PAHs, benzene, 
Table 5 Summary of studies analyzing upper aero-digestive cancer risk associated with household air pollution

\begin{tabular}{|c|c|c|c|c|c|c|}
\hline Cancer site & Study & $\begin{array}{l}\text { Cases } \\
(\mathrm{N})\end{array}$ & $\begin{array}{l}\text { Controls } \\
\text { (N) }\end{array}$ & Exposure definition & Odds ratio & Variables adjusted for \\
\hline \multirow[t]{4}{*}{ Oral } & Franco (1989) [23] & 232 & 464 & Exposure to wood stove & $2.50(1.60-3.90)$ & Age, sex, study site, admission period \\
\hline & Sapkota (2012) [7] & 295 & 1,018 & Coal users for $>50$ years & $1.26(0.46-3.47)$ & $\begin{array}{l}\text { Country, age, sex, BMI, pack years smoking, } \\
\text { alcohol, and dairy, red meat, fruits, vegetables. }\end{array}$ \\
\hline & Pintos (1998) [25] & 373 & 1,568 & $\begin{array}{l}\text { Woodstoves for cooking } \\
\text { and heating }\end{array}$ & $2.73(1.76-4.24)$ & $\begin{array}{l}\text { Socioeconomic, diet, employment, } \\
\text { alcohol tobacco }\end{array}$ \\
\hline & Dietz (1995) [24] & 100 & 400 & $\begin{array}{l}\text { Single stove heating units with } \\
\text { fossil fuel for }>40 \text { years }\end{array}$ & $2.40(1.26-4.40)$ & Smoking and alcohol \\
\hline \multirow[t]{6}{*}{ Nasopharyngeal } & Feng (2009) [15] & 636 & 615 & $\begin{array}{l}\text { Kanoun (compact oven of } \\
\text { charcoal) during childhood }\end{array}$ & $1.86(1.28-2.72)$ & $\begin{array}{l}\text { Stratified: sex, center; adjusted: age, } \\
\text { SES and diet }\end{array}$ \\
\hline & Jeannel (1990) [16] & 80 & 160 & $\begin{array}{l}\text { During childhood, kitchen } \\
\text { in main room }\end{array}$ & $1.76(0.73-4.27)^{* *}$ & None \\
\hline & Zheng (1994) [17] & 88 & 176 & Wood fire, poor ventilation & $2.14(0.94-8.87)^{* *}$ & None \\
\hline & Yu (1988) [26] & 128 & 174 & Exposure to wood and dry grass & $0.81(0.27-2.41)^{* *}$ & None \\
\hline & Yu (1986) [8] & 250 & 250 & Wood as cooking fuel & $1.51(1.03-2.21)^{* *}$ & None \\
\hline & Guo (2009) [19] & 1,049 & 785 & $>10$ years exposure to wood fire & $5.82(2.50-13.57)$ & Solvent exposures, smoking \\
\hline \multirow[t]{4}{*}{ Pharyngeal } & Pintos (1998) [25] & 217 & 1,568 & $\begin{array}{l}\text { Woodstoves for cooking } \\
\text { and heating }\end{array}$ & $3.82(1.96-7.42)$ & $\begin{array}{l}\text { Socioeconomic, diet, employment place, } \\
\text { alcohol and tobacco }\end{array}$ \\
\hline & Sapkota (2012) [7] & 201 & 1,040 & Coal users for $>50$ years & $3.00(0.30-30.46)$ & $\begin{array}{l}\text { Country, age, sex, BMI, pack years, alcohol, } \\
\text { and dairy, red meat, fruits, vegetables }\end{array}$ \\
\hline & Dietz (1995) [24] & 105 & 420 & $\begin{array}{l}\text { Single stove heating units with } \\
\text { fossil fuel for }>40 \text { years }\end{array}$ & $3.30(1.43-7.55)$ & Smoking and alcohol \\
\hline & Sapkota (2008) [14] & 513 & 718 & Coal use $>50$ years & $3.47(0.95-12.69)$ & $\begin{array}{l}\text { Age, sex, center, SES, smoking, alcohol, } \\
\text { chewing tobacco }\end{array}$ \\
\hline \multirow[t]{2}{*}{ Esophageal } & $\begin{array}{l}\text { Chang-Claude (1990) } \\
\text { [21] }\end{array}$ & 153 & 345 & Wood fuel use before 1970 & $2.60(0.07-9.20)$ & Household status \\
\hline & Sapkota (2012) [7] & 186 & 1,110 & Coal users $>50$ years & $1.50(0.48-4.71)$ & $\begin{array}{l}\text { Country, age, sex, BMl, pack years, alcohol, } \\
\text { and dairy, } \\
\text { red meat, fruits, vegetables }\end{array}$ \\
\hline \multirow[t]{3}{*}{ Laryngeal } & Maier (1997) [22] & 164 & 656 & $>40$ years fossil fuel single stove & $2.00(1.10-3.50)$ & Alcohol and tobacco \\
\hline & Sapkota (2012) [7] & 383 & 916 & Coal users for $>50$ years & $5.20(1.84-14.74)$ & $\begin{array}{l}\text { Country, age, sex, BMl, pack years, alcohol, } \\
\text { and dairy, red meat, fruits, vegetables }\end{array}$ \\
\hline & Sapkota (2008) [14] & 511 & 718 & Coal use $>50$ years & $3.65(1.11-11.93)$ & $\begin{array}{l}\text { Age, sex, center, SES, smoking, alcohol, } \\
\text { chewing tobacco }\end{array}$ \\
\hline
\end{tabular}


Table 5 Summary of studies analyzing upper aero-digestive cancer risk associated with household air pollution (Continued)

\begin{tabular}{cccccc}
\hline Pintos (1998) [25] & 194 & 1,568 & Woodstoves for cooking and heating & 2.34 (1.17 - 4.67) & $\begin{array}{l}\text { Socioeconomic, diet, employment place, alcohol and } \\
\text { tobacco }\end{array}$ \\
Dietz (1995) [24] & 164 & 656 & $\begin{array}{l}\text { Single stove heating units with fossil fuel for }> \\
40 \text { years }\end{array}$ & $2.00(1.10-3.46)$ & Smoking and alcohol
\end{tabular}

**No adjusted OR provided in the study. 
Table 6 Exploratory analyses based on type of fuel used

\begin{tabular}{|c|c|c|c|c|}
\hline \multirow[b]{2}{*}{ Cancer Site } & \multicolumn{2}{|l|}{ Coal } & \multicolumn{2}{|l|}{ Wood } \\
\hline & Studies & $\mathrm{OR}^{*}(95 \% \mathrm{Cl})$ & Studies & $\mathrm{OR}^{*}(95 \% \mathrm{Cl})$ \\
\hline Cervical & 1 & $3.46(1.08-11.10)$ & 2 & $10.29(3.27-32.40)$ \\
\hline Oral & 1 & 1.47 (0.19- 11.67) & 3 & $2.45(1.81-3.30)$ \\
\hline Nasopharyngeal & 1 & $1.86(1.28-2.72)$ & 5 & $1.77(1.07-2.91)$ \\
\hline Pharyngeal & 2 & $3.35(1.08-10.39)$ & 3 & $2.56(1.20-5.49)$ \\
\hline Esophageal & 1 & $1.50(0.48-4.71)$ & 2 & $2.13(1.05-4.30)$ \\
\hline Laryngeal & 2 & $4.45(2.03-9.74)$ & 3 & $1.54(0.81-2.94)$ \\
\hline
\end{tabular}

*Summary OR was calculated using fixed effects model for overall effect of each cancer site.

and 1,3-butadiene [5,33]. IARC concluded that HAP from combustion of coal was carcinogenic to humans (group 1) and that from wood was a probable carcinogen (group 2A) [4]. Studies found that coal smoke may potentially generate a higher carcinogenic potential than wood smoke for lung cancer [6]. However, research is needed to determine what constituent, or combination of constituents, of HAP is driving the carcinogenic potential. Given that the exposure depends on the type of fuel used [33] and the carcinogenic potential of the specific fossil fuel used [6], we explored the risk of our selected cancer sites by the type of fuel used. Although our analyses should be considered exploratory due to the limited number of fuel type specific results, it is interesting that our study suggestions that the risk associated with laryngeal cancers may be greater in populations with coal-specific exposures and the risk of cervical and oral cancers may be greater in those with wood-specific exposures.

Interesting evidence also emerges from our study that HAP is associated with increased risk of cervical neoplasia despite controlling for the risk factors such as HPV and smoking status [18]. There is limited mechanistic data available on how HAP may cause cervical neoplasia. However, in support of the hypothesis that HAP exposures may increase risk of cervical cancer, studies on cigarette smoking suggest that airborne nitrosoamines can be transmitted through blood to organs including cervix, thereby leading to cancer $[29,34]$. Therefore, it is conceivable that HAP exposures may mimic tobacco exposures with regard to cervical neoplasia risk. The causal mechanism for cervical neoplasia among HAP exposed warrants further investigation.

Our analysis has multiple strengths. This is the first meta-analysis to summarize the association between HAP and cancers other than lung. Though our study is a secondary data analysis we accounted for major risk factors to the extent possible by evaluating summary odds ratios based on study-specific ORs that adjusted for major confounders. Finally, the body of existing literature supports the biological plausibility for pathogenesis of these cancers. Even though we robustly reviewed the literature to identify all existing studies evaluating these associations, there were only a limited number of studies available for analysis. Another potential limitation is the file drawer effect of unpublished studies; however, our results are unlikely to be influenced by the file drawer effect, especially for upper aero-digestive tract, given the recent interest in $\mathrm{HAP}$ in relation to lung cancer [4]. We note, however, that even though the visual inspection of the funnel plots did not suggest the presence of publication bias, we cannot definitively rule out the possibility of publication bias. There were fewer than the 10 studies for each cancer site in this meta-analysis, which is the number of studies needed to draw formal conclusions on publication bias using the Begg's test [35].

\section{Conclusions}

Our results support the hypothesis that HAP is associated with the risk of cancers other than lung cancer. Our meta-analysis, however, should be considered hypothesis-generating until these associations are evaluated prospectively in order to overcome the limitations of the case-control design that was employed by virtually all of the studies included here.

\section{Additional file}

Additional file 1: Figure S1. Funnel plots for cancer site specific analyses

\section{Abbreviation}

95\% Cl: 95\% confidence intervals; OR: Adjusted odds ratios; CIN: Carcinoma in-situ; OR: Crude odds ratio; HAP: Household air pollution; HPV: Human papilloma virus; PAHs: Polycyclic aromatic hydrocarbons.

\section{Competing of interests}

The authors declare that they have no competing interests.

\section{Authors' contributions}

SJ and DH carried out the review of literature, designed the study and drafted the initial manuscript. JL and XX performed the statistical analysis. $\mathrm{NR}, \mathrm{QL}$, and DH conceived the study. SJ, JL, XX, NR, QL, TR, and DH reviewed and interpreted the results, and assisted in the drafting of the final manuscript.

\section{Author details}

${ }^{1}$ Department of Epidemiology \& Population Health, Albert Einstein College of Medicine, 1309, Belfer, Bronx New York, USA. ²Division of Cancer Epidemiology and Genetics, National Cancer Institute, Bethesda, MD, USA. 
Received: 5 November 2014 Accepted: 4 February 2015

Published online: 15 March 2015

\section{References}

1. Smith KR, Mehta S. The burden of disease from indoor air pollution in developing countries: comparison of estimates. Int J Hyg Environ Health. 2003;206:279-89.

2. Manish A. Desai SM, Kirk R. Smith Indoor smoke from solid fuels. Assessing the environmental burden of disease at national and local levels World Health Organization 2004, Environmental Burden of Disease Series, No. 4

3. Lim SS, Vos T, Flaxman AD, Danaei G, Shibuya K, Adair-Rohani H, et al. A comparative risk assessment of burden of disease and injury attributable to 67 risk factors and risk factor clusters in 21 regions, 1990-2010: a systematic analysis for the Global Burden of Disease Study 2010. Lancet. 2013;380:2224-60.

4. Straif K, Baan R, Grosse Y, Secretan B, El Ghissassi F, Cogliano V. Carcinogenicity of household solid fuel combustion and of high-temperature frying. Lancet Oncol. 2006;7:977-8.

5. Hosgood HD, Wei H, Sapkota A, Choudhury I, Bruce N, Smith KR, et al. Household coal use and lung cancer: systematic review and meta-analysis of case-control studies, with an emphasis on geographic variation. Int J Epidemiol. 2011;40:719-28.

6. Hosgood H, Boffetta P, Greenland S, Lee Y-CA, McLaughlin J, Seow A, et al. In-home coal and wood use and lung cancer risk: a pooled analysis of the International Lung Cancer Consortium. Environ Health Perspect. 2010;118:1743-7.

7. Sapkota A, Zaridze D, Szeszenia-Dabrowska N, Mates D, Fabiánová E, Rudnai $P$, et. al.: Indoor air pollution from solid fuels and risk of upper aerodigestive tract cancers in Central and Eastern Europe. Environmental research 2012.

8. Yu MC, Ho JH, Lai S-H, Henderson BE. Cantonese-style salted fish as a cause of nasopharyngeal carcinoma: report of a case-control study in Hong Kong. Cancer Res. 1986;46:956-61.

9. Lin T, Chen K, Lin C, Hsu M, Tu S, Chiang T, et al. Retrospective study on nasopharyngeal carcinoma. J Natl Cancer Inst. 1973;51:1403-8.

10. Armstrong RW, Armstrong MJ, Mimi CY, Henderson BE. Salted fish and inhalants as risk factors for nasopharyngeal carcinoma in Malaysian Chinese. Cancer Res. 1983;43:2967-70.

11. Wu M-T, Lee L-H, Ho C-K, Wu S-C, Lin L-Y, Cheng B-H, et al. Environmental exposure to cooking oil fumes and cervical intraepithelial neoplasm. Environ Res. 2004;94:25-32.

12. Lee $\mathrm{CH}$, Yang SF, Peng CY, Li RN, Chen YC, Chan TF, et al. The precancerous effect of emitted cooking oil fumes on precursor lesions of cervical cancer. Int J Cancer. 2010;127:932-41.

13. Sierra Torres $\mathrm{CH}$, Acosta Aragón MP, Orejuela Aristizabal L. Papilomavirus y factores asociados a neoplasia intraepitelial cervical de alto grado en Cauca, Colombia. Rev Salud Publica. 2006;8:47-58.

14. Sapkota A, Gajalakshmi V, Jetly DH, Roychowdhury S, Dikshit RP, Brennan P, et al. Indoor air pollution from solid fuels and risk of hypopharyngeal/ laryngeal and lung cancers: a multicentric case-control study from India. Int J Epidemiol. 2008;37:321-8.

15. Feng B, Khyatti M, Ben-Ayoub W, Dahmoul S, Ayad M, Maachi F, et al. Cannabis, tobacco and domestic fumes intake are associated with nasopharyngeal carcinoma in North Africa. Br J Cancer. 2009;101:1207-12.

16. Jeannel D, Hubert A, De Vathaire F, Ellouz R, Camoun M, Ben Salem M, et al. Diet, living conditions and nasopharyngeal carcinoma in tunisia-a casecontrol study. Int J Cancer. 1990;46:421-5.

17. Zheng Y, Tuppin P, Hubert A, Jeannel D, Pan Y, Zeng Y. Environmental and dietary risk factors for nasopharyngeal carcinoma: a case-control study in Zangwu County, Guangxi. China British journal of cancer. 1994;69:508.

18. Velema JP, Ferrera A, Figueroa M, Bulnes R, Toro LA, de Barahona O, et al. Burning wood in the kitchen increases the risk of cervical neoplasia in HPV-infected women in Honduras. Int J Cancer. 2002;97:536-41.

19. Guo X, Johnson RC, Deng H, Liao J, Guan L, Nelson GW, et al. Evaluation of nonviral risk factors for nasopharyngeal carcinoma in a high-risk population of Southern China. Int J Cancer. 2009;124:2942-7.

20. Ferrera A, Velema JP, Figueroa M, Bulnes R, Toro LA, Claros JM, et al. Co-factors related to the causal relationship between human papillomavirus and invasive cervical cancer in Honduras. Int J Epidemiol. 2000;29:817-25.

21. Chang-Claude JC, Wahrendorf J, Liang QS, Rei YG, Muñoz N, Crespi M, et al. An epidemiological study of precursor lesions of esophageal cancer among young persons in a high-risk population in Huixian, China. Cancer Res. 1990;50:2268-74.

22. Maier H, Tisch M. Epidemiology of laryngeal cancer: results of the Heidelberg case-control study. Acta Otolaryngol. 1997;117:160-4.

23. Franco EL, Kowalski LP, Oliveira BV, Curado MP, Pereira RN, Silva ME, et al. Risk factors for oral cancer in Brazil: a case-control study. Int J Cancer. 1989:43:992-1000.

24. Dietz A, Senneweld E, Maier H. Indoor air pollution by emissions of fossil fuel single stoves: possibly a hitherto underrated risk factor in the development of carcinomas in the head and neck. Otolaryngol Head Neck Surg. 1995;112:308-15.

25. Pintos J, Franco EL, Kowalski LP, Oliveira BV, Curado MP. Use of wood stoves and risk of cancers of the upper aero-digestive tract: a case-control study. Int J Epidemiol. 1998;27:936-40.

26. Yu MC, Mo C-C, Chong W-X, Yeh F-S, Henderson BE. Preserved foods and nasopharyngeal carcinoma: a case-control study in Guangxi, China. Cancer Res. 1988:48:1954-9.

27. Anisimov VN, Zabezhinski MA, Popovich IG, Zaripova EA, Musatov SA, Andre $V$, et al. Inhibitory effect of melatonin on 7, 12-dimethylbenz $[<\mathrm{i}>\mathrm{a}</ \mathrm{i}\rangle]$ anthracene-induced carcinogenesis of the uterine cervix and vagina in mice and mutagenesis in vitro. Cancer Lett. 2000;156:199-205.

28. Chiang T-A, Wu P-F, Wang L-F, Lee H, Lee C-H, Ko Y-C. Mutagenicity and polycyclic aromatic hydrocarbon content of fumes from heated cooking oils produced in Taiwan. Mutat Res Fundam Mol Mech Mutagen. 1997;381:157-61.

29. Scully C, Field J, Tanzawa H. Genetic aberrations in oral or head and neck squamous cell carcinoma (SCCHN): 1. Carcinogen metabolism DNA repair and cell cycle control. Oral Oncol. 2000;36:256-63.

30. Tung Y-H, Ko J-L, Liang Y-F, Yin L, Pu Y, Lin P. Cooking oil fume-induced cytokine expression and oxidative stress in human lung epithelial cells. Environ Res. 2001;87:47-54.

31. Organization WH: IARC Monographs on the evaluation of carcinogenic risks to humans. IARC Working Group on the Evaluation of Carcinogenic Risks to Humans 2007, 89

32. Hosgood III HD, Berndt SI, Lan Q. GST< genotypes and lung cancer susceptibility in Asian populations with indoor air pollution exposures: a meta-analysis. Mutat Res Rev Mutat Res. 2007;636:134-43.

33. Hu W, Downward GS, Reiss B, Xu J, Bassig B, Hosgood D, et al. Personal and indoor PM2. 5 exposure from burning solid fuels in vented and unvented stoves in a rural region of China with a high incidence of lung cancer. Environ Sci Technol. 2014;48(15):8456-64.

34. Sasson IM, Haley NJ, Hoffmann D, Wynder EL, Hellberg D, Nilsson S. Cigarette smoking and neoplasia of the uterine cervix: smoke constituents in cervical mucus. N Engl J Med. 1985;312:315-6.

35. Begg CB, Mazumdar M: Operating characteristics of a rank correlation test for publication bias. Biometrics 1994:1088-1101

\section{Submit your next manuscript to BioMed Central and take full advantage of:}

- Convenient online submission

- Thorough peer review

- No space constraints or color figure charges

- Immediate publication on acceptance

- Inclusion in PubMed, CAS, Scopus and Google Scholar

- Research which is freely available for redistribution 